Sofie Decock, July De Wilde*, Sarah Van Hoof, Ellen Van Praet and Bernard De Clerck

\title{
Professional discourse
}

\section{in multilingual settings: policies and practices}

https://doi.org/10.1515/multi-2018-0023

Keywords: multilingualism, professional discourse, sociolinguistics, international business studies

\section{Workplace multilingualism in sociolinguistics and international business studies}

With the growth in mobility and linguistic diversity as some of the hallmarks of our increasingly globalized economy, research addressing multilingualism in the workplace has been on the rise. Both scholars in sociolinguistics and in international business studies have developed an interest in workplace multilingualism. The former continue a longstanding research tradition on workplace discourse in various disciplines of linguistics, ranging from ethnomethodology and conversation analysis to ethnography, pragmatics, (critical) discourse analysis and interactional sociolinguistics (e.g. Drew and Heritage 1992; Gumperz 1982; Gunnarsson et al. 1997; for an overview, see Sarangi and Roberts 1999). Many of these studies have combined a focus on the fine detail of micro-level interactions with one on the institutional order and larger-scale social, economic and ideological processes, and have laid bare the generic features of workplace talk, how institutional knowledge and professional identity are constructed in discourse (Sarangi and Roberts 1999), and how (mis)communication can feed processes of racial discrimination in multi-ethnic workplaces or cross-cultural service encounters (Gumperz et al. 1979; Gumperz and Roberts 1991; Roberts

\footnotetext{
*Corresponding author: July De Wilde, Department of Translation, Interpreting and Communication, Ghent University, Groot-Brittanniëlaan 45, Gent, Belgium, E-mail: july.dewilde@ugent.be
}

Sofie Decock: E-mail: sofie.decock@ugent.be, Sarah Van Hoof: E-mail: sarah.vanhoof@ugent. be, Ellen Van Praet: E-mail: ellen.vanpraet@ugent.be, Bernard De Clerck: E-mail: bernard. declerck@ugent.be, Department of Translation, Interpreting and Communication, Ghent University, Groot-Brittanniëlaan 45, Gent, Belgium 
et al. 1992). More recent sociolinguistic studies (which Angouri and Piekkari designate as the "young but established field of workplace sociolinguistics" (2018: 10)) vary in their attention to the fine interactional detail, but mostly share the concern for a 'thick description' (Geertz 1973) of workplace discourse with the earlier studies, and often draw on the assumptions and the techniques of ethnography, or on what has come to be called 'linguistic ethnography' (Rampton et al. 2015), to describe the impact of multilingualism in contemporary workplaces. Often taking a critical stance, these studies draw attention to the role that the knowledge of a given set of linguistic resources plays in managing professional relations and in getting access to material and symbolic resources (e.g. jobs and services), and in doing so highlight the ways in which language is implicated in gatekeeping processes and in social mobility (or the lack of it) (see e.g. the contributions to Duchêne et al. 2013).

Parallel to the sociolinguistic research on workplace discourse, researchers in the field of international business (IB) have devoted attention to the role of language in international business since the 1970s, resulting in the subfield of "language-sensitive international management research" (Lecomte et al. 2018: 2). In recent years, a partial convergence with sociolinguistics can be observed. In particular, a number of scholars in the field of language-sensitive IB studies have called for and made successful attempts at incorporating theoretical concepts and methodologies from sociolinguistics (Janssens and Steyaert 2014; Lecomte et al. 2018; Angouri and Piekkari 2018). They argue that in the light of the 'linguistic' or 'discursive' turn in the humanities and social sciences, some key concepts within IB studies, such as 'language' and 'organisation', need to be revisited. In line with recent reconceptualizations of language in sociolinguistics (e.g. Blommaert 2010; Canagarajah 2007; Martin-Jones et al. 2012), they advocate a departure from the traditional instrumental view of language as a bounded and stable system and as a variable which can easily be 'managed', in favour of a view of language as a set of repertoires or web of linguistic resources unequally distributed and mobilized by speakers in very complex ways in actual practice. In addition, they argue that a simplistic understanding of an organisation as a homogeneous setting should likewise be abandoned in favour of more complex and dynamic conceptualisations. Moreover, they point out that multilingualism should not only be approached from an elite managerial perspective, paying attention to top-down language policies in multinational corporations (MNCs) and in the context of international joint ventures, mergers and acquisitions (e.g. Piekkari et al. 2005). Instead, attention should also be paid to multilingualism from the employee perspective, looking into the daily language practices of both high- and low-status employees, which "do not always correspond to the prescribed policies, but are much more flexible and creative", thus 
recognizing employees "as agents shaping everyday practices at their workplaces” (Lecomte et al. 2018: 3; see also e.g. Fredriksson et al. 2006; Peltokorpi and Vaara 2012; Lønsmann and Kraft in this issue).

Also in terms of research foci, commonalities between both strands can be observed. A common topic in recent sociolinguistic and IB studies on the multilingual workplace is the interplay between language and power. Differential and potentially changing valorizations of linguistic repertoires in contemporary workplaces have been shown to result in the hierarchization of linguistic resources (Duchêne 2011; Muth and Del Percio 2017). Those with a command in the languages which are most dominant or valuable from a political and economic point of view (often national or standard languages) tend to be in more advantageous positions in terms of access to work and positions of power in the workplace (Duchêne et al. 2013). Top-down language policies which give the corporate language a superior status vis-à-vis other languages spoken by employees either in the headquarters or in subsidiaries, often generate ingroup-outgroup divisions, social exclusion or status inequality (Neeley 2013; Neeley and Dumas 2016; Harzing and Pudelko 2013; Hinds et al. 2014; Piekkari et al. 2005; Lønsmann 2014; Lønsmann 2015; Lønsmann 2017). In other words, multilingualism in workplaces in the globalized economy can boast social mobility and open doors, but it can, just as much, sustain hierarchies, create inequalities and keep doors shut for those who do not, or no longer, possess the 'right' multilingual repertoires (Duchêne et al. 2013; see also Lønsmann and Kraft and De Wilde et al. in this issue).

Another recurring topic, especially within workplace sociolinguistics, is the commodification of language, referring to the way in which language is turned into a commodity, i.e. a resource possessing economic exchange value (Heller 2003; Heller 2010; Heller and Duchêne 2016; Muth and Del Percio 2017). The globalized new economy, characterized, among others, by the growth of the service sector, is seen to "lead to an increasingly central economic role for language, both as the means through which work is accomplished (the work process) and as a product of labor (the work product)" (Heller 2010: 104). The economic success of organizations is seen to depend more than ever on the efficiency of internal and external communication flows. This very notion of 'efficient' communication has had "a commodifying effect on the understanding of language” (Angouri and Piekkari 2018: 14). Language competences have come to be conceptualized as measurable and assessable 'skills' (Urciuoli 2008; Urciuoli 2016). Workers possessing the 'right' language skills to function efficiently within an organization or to be able to cater to niche markets (cf. Heller 2010) are considered to provide an added value for companies (see also Wodak and Krzyzanowski 2010, on the conceptualisation of multilingualism in economic terms in EU language policy). 
Although workplace sociolinguistics and language-sensitive IB have definitely grown closer together as disciplines, they still clearly differ in their positioning vis-à-vis theorizing and practical relevance (cf. Sarangi and Roberts 1999: 39). The main focus of language-sensitive IB research lies on understanding the dynamics and consequences of management processes in organizations, and the complex role of multilingualism therein. One of its aims is the translation of research findings into managerial implications (e.g. how to create non-normative language policies that allow to "mov[e] beyond any singular norm which inevitably leads to a particular form of social exclusion" (Janssens and Steyaert 2014: 634); see also Kankaanranta et al. and Van der Worp et al. in this issue). Within sociolinguistics, on the other hand, many studies have critically commented on how, through language, structures of (in)equality are (re)produced or challenged in work contexts. Not all scholars working in this strand, however, have the aim of applying their research to solving practical problems or formulating advice to overcome the observed inequalities. While also documenting acts of resistance through which power relations are partially subverted, this type of work at the same time acknowledges that forms of resistance can create their own sets of hierarchies and tensions (Duchêne et al. 2013; see Lønsmann and Kraft and De Wilde et al. in this issue).

\section{Aim of this issue}

This special issue inscribes itself in the recent development of growing convergence between sociolinguistic approaches to multilingualism in the workplace and language-sensitive IB research. We want to pick up on recent work in both fields and further explore the ambivalent nature of multilingualism in professional settings. In September 2015, we hosted the international conference "Multilingual Perspectives on Professional Discourse in Europe" at Ghent University (Belgium). This special issue includes a selection of papers which were presented at this conference. They address multilingualism in a variety of workplace settings, some of which are still relatively underresearched (Angouri and Piekkari 2018). Indeed, the papers focus on multilingualism not only in MNCs (Kankaanranta, Karhunen and Louhiala-Salminen), but also in more locally oriented businesses in a region with more than one national language (Van der Worp, Cenoz and Gorter), in workplaces in the production economy, with a specific focus on low-status workers in the logistics and construction sectors (Lønsmann and Kraft), and in a public institution providing healthcare 
and social services (De Wilde, Van Hoof, Decock, Rillof and Van Praet). All papers document European contexts (The Basque Autonomous Community (Spain), Flanders (Belgium), Denmark and Norway).

Overall, the papers address the following research questions:

- How do processes characterizing the current globalized economy, such as the internationalisation of companies, migration and the concomitant increased ethnolinguistic diversity, and neoliberal economic practices affect the conceptualisation of language and language policies?

- How can the role of English as a lingua franca in contemporary business communication be conceptualised, and how is it played out in practice?

- What repertoires, consisting of linguistic and other semiotic means, are mobilized by workers in multilingual workplaces?

- How do these practices, carried out on the workfloor, relate to official, topdown language policies devised by companies or imposed by the state?

- What are the in- and exclusionary effects of language policies and practices in contemporary workplaces? Which groups benefit from the current corporate or institutional regimes, and which ones are marginalized?

- What attitudes and language ideologies can be registered in the contemporary multilingual workplace?

Each contribution to this special issue focuses on one or several of these questions, approaching multilingualism in the workplace on the basis of varying datasets, ranging from recordings of naturally occurring interactions over policy documents to interviews and questionnaires, and with various complementary analytical methods.

\section{Overview of the special issue}

The opening article of this special issue calls for a corporate language policy with emancipatory potential, which presupposes knowledge about the links between language and power and builds on a greater awareness of the complex, multifaceted role of language in international business. Kankaanranta, Karhunen and Louhiala-Salminen approach the issue from a language-sensitive IB perspective, intertwining their views with insights from sociolinguistics. The authors explore the notion of 'English as a corporate language', arguing for a two-pronged conceptualization: MNCs' official language represents the voice of the corporation, for which the use of standard English (ENL) is taken for granted, while in interactions of individual employees 'working language' BELF (English a Business Lingua Franca) 
is used. In making this distinction, Kankaanranta et al. draw on Goffman's (1959) seminal work on backstage and frontstage behavior, much in line with Sarangi and Roberts' (1999) earlier call to study both 'frontstage' professional-client encounters and 'backstage' work activities in order to reach a "holistic" understanding of workplace communication (1999: 20). Kankaanranta et al. deploy Goffman's metaphor to work towards language policy recommendations: to alleviate the power imbalance between employees mastering the 'official English' and those who do not, the authors insist that multinational companies should accept different standards of English for different positions and encourage employees to 'get the job done', instead of calling for native-like competence. They also plead for re-thinking in-company language training, emphasizing communicative competence instead of linguistic proficiency.

Van der Worp, Cenoz and Gorter offer an account of processes of hierarchisation and competitive tensions between languages in the workplace, which are rooted both in differences in international economic prestige and in a history of sociocultural oppression and resistance. They focus on the specific context of the Basque Autonomous Community (BAC) in Spain, where the minority language of Basque is being promoted by the regional government for reasons of cultural and identity preservation, and where the majority language of Spanish receives its legitimacy through its status of international language, which even enables a partial circumvention of the dominance of English for international trade. Drawing on policy documents and interview data, the authors identify the challenges for the use of Basque as a minority language in internationally oriented workplaces in Basque Country. They point out how the discourse of cultural and linguistic preservation that underpins minority language 'normalization' efforts may sit uncomfortably with economic interests, which prioritize languages guaranteeing access to international markets (cf. Barakos 2012; Heller and Duchêne 2012), and which in this context therefore favour the use of Spanish and English over Basque. Van der Worp et al.'s findings prompt them to call for multilingual language management strategies which ensure the coexistence of the three languages.

De Wilde, Van Hoof, Decock, Rillof and Van Praet discuss the hierarchization of linguistic resources, and the consequent capitalization or decapitalization of the workers possessing them (Duchêne 2011), in the context of a public service provider in the domain of child healthcare. Drawing on ethnographic data, the authors focus on the restrictions imposed on the routinized bilingual practices developed by family support workers and medical staff, and on the way in which the organization's management legitimizes these restrictions. The paper highlights that the employees' ability to develop bottom-up linguistic practices are prone to contextual pressures, in this case capped budgets: while the family support workers' routine bilingual practices were initially endorsed by management as 
in line with the 'client-centered communication' central to the organization, budgetary restrictions led to a reorganisation which considerably reduced the family support workers' room for manoeuvre and led to a resignification of their professional identity. The discursive legitimation of this reorganisation illustrates how even the public sector is influenced by neoliberal logics centering around efficiency and flexibility, affecting its conceptualisation of communicative competence and its human resources management at large, a reality which has long been associated first and foremost with corporate settings.

Finally, Lønsmann and Kraft's ethnographic study lays bare the effects of increasing multilingualism in workplaces in the production economy, more specifically logistics and construction sites in Denmark and Norway respectively. They demonstrate that language policies in these workplaces, similar to established management practices in other sectors, are anchored in neoliberal logics of internationalisation and commodification. These policies are seen to reproduce the existing social hierarchy of these sites by valorizing the linguistic repertoires of highstatus employees (i.e. English and/or Scandinavian languages), while erasing the everyday linguistic practices and repertoires of their subordinates. As a result, these policies do not benefit the low-status workers in the same way as they benefit management, and they can also limit the professional mobility of low-status workers.

From the overview of this special issue, it becomes clear that all contributions discuss processes of hierarchisation and commodification in partly similar, partly different ways. It comes as no surprise that in all workplace settings which are studied in this issue, certain languages have acquired a prestigious position to the disadvantage of others. Their position can mainly be attributed to the perceived added value of these languages in the new globalized economy, i.e. the extent to which they are seen to be able to contribute to the business goal of achieving international success and profit. Most often, this goal is thought to be best fulfilled by English (cf. Kankaanranta et al., Lønsmann and Kraft, and Van der Worp et al. in this issue), or specific national languages which have the potential of increasing cross-border sales (Spanish in the case of Van der Worp et al.). Not only the local national language usually has a privileged position, but in some cases also closely related languages, perceived as highly similar to this official national language (Swedish and Norwegian, in the Norwegian construction site described by Lønsmann and Kraft), thus delineating a common (trans)national identity against the background of one nation-one language ideologies. When languages with a minority status (Basque in the case of Van der Worp et al. and Turkish and Arabic in the case of De Wilde et al.) gain some amount of visibility and recognition, incentives for this seem to be language revitalization policies as designed and implemented by regional political governments (Van der Worp et al.), or a customer or client-oriented attitude that is 
deemed necessary for adequate service provision (Van der Worp et al. resp. De Wilde et al.). The way the latter is implemented, however, not only depends on ideological considerations but also on material constraints, limited budgets working to the detriment of minority languages.

All contributions point to the consequences that language policies which privilege certain languages over others in the workplace have for the workers. On the one hand, such language policies tend to protect and reproduce the privilege of high-status employees, who usually are competent in the chosen corporate languages, while disadvantaging low-status employees, whose 'other' multilingual repertoires are rendered invisible and whose lower levels of competence in the 'right' linguistic repertoires decrease their chances for professional mobility (Lønsmann and Kraft). Both Kankaanranta et al. and Van der Worp et al. formulate the need to develop multilingual language policies which try to alleviate these language-related power imbalances. Designing such policies would require the abandonment of the norm of native-like competence (Kankaanranta et al.), efforts to counterbalance the criterion of the internationalisation potential of a language (Van der Worp et al.), or efforts to valorise the linguistic repertoires of low-status employees (Lønsmann and Kraft).

Several contributions reveal processes of erasure (Irvine and Gal 2000) in the ways in which policies conceptualise language and communication in the workplace. In a drive for efficiency, policy makers confound 'soft' communication competences with the 'hard' knowledge of specific languages in the case of De Wilde et al.; in Lønsmann and Kraft's case the policies render invisible the multisemiotic and multilingual nature of workplace communication. In the former case, the management seems to overestimate the medical staff's ability to overcome linguistic boundaries by multisemiotic means, whereas in the latter they seem to underestimate manual workers' capacity to do the same. This shows that a detailed and contextualized view on in situ linguistic practices is key for understanding communication in the workplace, as well as for pinpointing the ideological and practical consequences of language policies on workers' daily practices and their position in workplace hierarchies.

\section{References}

Angouri, Jo. 2014. Multilingualism in the workplace: language practices in multilingual contexts. Multilingua 33(1-2). 1-9.

Angouri, Jo \& Rebecca Piekkari. 2018. Organising multilingually: setting an agenda for studying language at work. European Journal of International Management 12(1-2). 8-27. 
Barakos, Elisabeth. 2012. Language policy and planning in urban professional settings: bilingualism in Cardiff businesses. Current Issues in Language Planning 13(3). 167-186.

Blommaert, Jan. 2010. The sociolinguistics of globalization. Cambridge: Cambridge University Press.

Canagarajah, Suresh. 2007. Lingua franca English, multilingual communities, and language acquisition. The Modern Language Journal 91. 923-939.

Drew, Paul \& John Heritage (eds.). 1992. Talk at work. Interaction in institutional settings. Cambridge: Cambridge University Press.

Duchêne, Alexandre. 2011. Néolibéralisme, inégalités sociales et plurilinguismes: l'exploitation des ressources langagières et des locuteurs. Langage et Société 136. 81-108.

Duchêne, Alexandre, Melissa Moyer \& Celia Roberts. 2013. Introduction: recasting institutions and work in multilingual and transnational spaces. In Alexandre Duchêne, Melissa Moyer \& Celia Roberts (eds.), Language, migration and social inequalities: $A$ critical sociolinguistic perspective on institutions and work, 1-21. Bristol: Multilingual Matters.

Fredriksson, Riika, Wilhelm Barner-Rasmussen \& Rebecca Piekkari. 2006. The multinational corporation as a multilingual organisation: The notion of a common corporate language. Corporate Communications: An International Journal 11. 406-423.

Geertz, Clifford. 1973. The interpretation of cultures. New York: Basic Books.

Goffman, Erving. 1959. The presentation of self in everyday life. New York: Doubleday. Gumperz, John. 1982. Discourse strategies. Cambridge: Cambridge University Press.

Gumperz, John, Tom Jupp \& Celia Roberts. 1979. Crosstalk. London: National Centre for Industrial Language Training.

Gumperz, John \& Celia Roberts. 1991. Understanding in intercultural encounters. In Jan Blommaert \& Jef Verschueren (eds.), The pragmatics of international and intercultural communication, 51-90. Amsterdam/Philadelphia: John Benjamins.

Gunnarsson, B.-L., P. Linell \& B. Nordberg 1997. The construction of professional discourse. London: Longman.

Harzing, Anne-Wil \& Markus Pudelko. 2014. Hablas vielleicht un peu la mia language? A comprehensive overview of the role of language differences in headquarters-subsidiary communication. The International Journal of Human Resource Management 25. 696-717.

Heller, Monica. 2003. Globalization, the new economy, and the commodification of language and identity. Journal of Sociolinguistics 7. 473-492.

Heller, Monica. 2010. The commodification of language. Annual Review of Anthropology 39. 101-114.

Heller, Monica \& Alexandre Duchêne. 2012. Pride and profit: Changing discourses of language, capital and nation-state. In Alexandre Duchêne \& Monica Heller (eds.), Language in late capitalism. Pride and profit, 1-21. New York: Routledge.

Heller, Monica \& Alexandre Duchêne. 2016. Treating language as an economic resource. In Nikolas Coupland (ed.), Sociolinguistics: Theoretical debates, 139-156. Cambridge: Cambridge University Press.

Hinds, Pamela J., Tsedal B. Neeley \& Catherine Durnell Cramton. 2014. Language as lightning rod: Power contests, emotion regulation, and subgroup dynamics in global teams. Journal of International Business Studies 45(5). 536-561.

Irvine, Judith T. \& Susan Gal. 2000. Language ideology and linguistic differentiation. In Paul V. Kroskrity (ed.), Regimes of Language. Ideologies, polities, and identities, 35-84. Santa Fe: School of American Research Press. 
Janssens, Maddy \& Kris Steyaert. 2014. Re-considering language within a cosmopolitan understanding: Toward a multilingual franca approach in international business studies. Journal of International Business Studies 45. 623-639.

Lecomte, Philippe, Helene Tenzer \& Ling Eleanor Zhang. 2018. Introduction. European Journal of International Management 12(1-2). 1-7.

Lønsmann, Dorte. 2014. Linguistic diversity in the international workplace: Language ideologies and processes of exclusion. Multilingua 33(1-2). 89-116.

Lønsmann, Dorte. 2015. Language ideologies in a Danish company with English as a corporate language: 'it has to be English'. Journal of Multilingual and Multicultural Development 36 (4). 339-356.

Lønsmann, Dorte. 2017. Embrace it or resist it? Employees' reception of corporate language policies. International Journal of Cross Cultural Management 17(1). 101-123.

Martin-Jones, Marilyn, Adrian Blackledge \& Angela Creese. 2012. Introduction: A sociolinguistics of multilingualism for our times. In Marilyn Martin-Jones, Adrian Blackledge \& Angela Creese (eds.), The Routledge handbook of multilingualism, 1-26. Abingdon: Routledge.

Muth, Sebastian \& Alfonso Del Percio. 2017. Policing for commodification: Turning communicative resources into commodities. Language Policy. 1-7.

Neeley, Tsedal B. 2013. Language matters: Status loss and achieved status distinctions in global organizations. Organization Science 24(2). 476-497.

Neeley, Tsedal \& Tracy Dumas. 2015. Unearned status gain: Evidence from a global language mandate. Academy of Management Journal 59. 14-43.

Peltokorpi, Vesa \& Eero Vaara. 2012. Language policies and practices in wholly owned foreign subsidiaries: A recontextualization perspective. Journal of International Business Studies 43(9). 808-833.

Piekkari, Rebecca, Eero Vaara, Janne Tienari \& Risto Säntti. 2005. Integration or disintegration? Human resource implications of a common corporate language decision in a cross-border merger. International Journal of Human Resource Management 16(3). 333-347.

Rampton, Ben, Janet Maybin \& Celia Roberts. 2015. Theory and method in linguistic ethnography. In Julia Snell, Sara Shaw \& Fiona Copland (eds.), Linguistic ethnography. Interdisciplinary explorations, 14-50. London: Palgrave Macmillan.

Roberts, Celia, Evelyn Davies \& Tom Jupp. 1992. Language and discrimination: A study of communication in multi-ethnic workplaces. London: Longman.

Sarangi, Srikant \& Celia Roberts. 1999. The dynamics of interactional and institutional orders in work-related settings. In Srikant Sarangi \& Celia Roberts (eds.), Talk, work and institutional order. Discourse in medical, mediation and management settings, 1-56. Berlin/New York: Mouton de Gruyter.

Urciuoli, Bonnie. 2008. Skills and selves in the new workplace. American Ethnologist 35(2). 211-228.

Urciuoli, Bonnie. 2016. The compromised pragmatics of diversity. Language and Communication (51). 30-39.

Wodak, Ruth \& Michat Krzyżanowski. 2010. Hegemonic multilingualism in/of the EU institutions: An inside-outside perspective on European language policies. In Cornelia Hülmbauer \& Eva Vetter (eds.), Mehrsprachigkeit aus der Perspektive zweier EU- Projekte: DYLAN meets LINEE, 115-134. Frankfurt am Main: Peter Lang. 